\title{
Candidate gene polymorphisms and risk of psoriasis: A pilot study
}

\author{
ALEJANDRA VILLARREAL-MARTÍNEZ ${ }^{1}$, HUGO GALLARDO-BLANCO ${ }^{2}$, \\ RICARDO CERDA-FLORES ${ }^{3}$, IRIS TORRES-MUÑOZ ${ }^{2}$, MINERVA GÓMEZ-FLORES ${ }^{1}$, \\ JULIO SALAS-ALANIIS ${ }^{1}$, JORGE OCAMPO-CANDIANI ${ }^{1}$ and LAURA MARTÍNEZ-GARZA ${ }^{2}$ \\ Departments of ${ }^{1}$ Dermatology and ${ }^{2}$ Genetics, University Hospital ‘Dr. José Eleuterio González'; \\ ${ }^{3}$ Population Genetics Department, School of Nursing, Autonomous University of Nuevo León, \\ Monterrey, Nuevo León 64460, México
}

Received November 3, 2014; Accepted October 22, 2015

DOI: $10.3892 / \mathrm{etm} .2016 .3066$

\begin{abstract}
Psoriasis is a complex genetic disease, which has previously been associated with numerous single nucleotide polymorphisms (SNPs) that are implicated in various processes, including skin barrier functions and in the regulation of inflammatory and immune responses. The present study aimed to investigate the genotypic and allelic frequencies of 32 SNPs at 24 genetic loci, and their association with psoriasis in a Mexican population. These SNPs, which were associated with psoriasis in previous studies, included the following genes: Major histocompatibility complex class I-C (HLA-C), interleukin $(I L)-12 B$, $I L-23 R, I L-23 A, I L-28 R A$, tumor necrosis factor $(T N F)-\alpha$, ring finger protein-114 (RNF114), cyclin-dependent kinase 5 regulatory subunit-associated protein 1-like 1, late cornified envelope $3 \mathrm{~B} / 3 \mathrm{C}$, signal transducer and activator of transcription 4, LINC01185, interferon induced with helicase C domain 1, IL-13, TNF- $\alpha$-induced protein 3 (TNFAIP3), TNFAIP3 interacting protein 1, endoplasmic reticulum aminopeptidase $1, T N F$ receptor-associated factor interacting protein 2, Leptin, nuclear factor of kappa light polypeptide gene enhancer in B-cells inhibitor-alpha, F-box and leucine-rich repeat protein 19 , nitric oxide synthase 2 , cluster of differentiation 40, nuclear receptor coactivator 5 , and ADAM metallopeptidase domain 33. A total of 32 male and 14 female subjects with a clinical diagnosis of chronic plaque psoriasis, as well as 103 control subjects, were analyzed. Molecular analyses were performed using TaqMan ${ }^{\circledR}$ assays in a TaqMan ${ }^{\circledR}$ OpenArray ${ }^{\circledR}$ Genotyping system. Results were analyzed using the Golden Helix SNP and Variation Suite 7 program. Of the 32 SNPs, six were associated with an increased risk of developing psoriasis, including: $H L A-C$
\end{abstract}

Correspondence to: Dr Laura Martínez-Garza, Department of Genetics, University Hospital 'Dr. José Eleuterio González', Francisco I. Madero Avenue and José Eleuterio Gonzalitos Avenue, Mitras Centro, Monterrey, Nuevo León 64460, México

E-mail: laelmar@yahoo.com.mx

Key words: psoriasis genes, polymorphisms, gene association, genetic risk rs10484554 [allele T: odds ratio (OR) 3.51], $I L-12 B$ rs3212227 (allele T: OR 1.88), $I L-12 B$ rs3213094 (allele C: OR 1.94), HLA complex group 27 rs1265181 (allele C: OR 2.83), annexin A6 rs17728338 (allele A: OR 2.41), and RNF114 rs6125829 (allele G: OR 1.98). Fisher's exact test detected statistical significance; however, following false discovery rate and Bonferroni correction, this association was no longer significant (threshold for genome-wide significance, $\mathrm{P}<1.56 \times 10^{-3}$ ). SNPs that were associated with an increased risk of psoriasis in the present study have previously been associated with psoriasis in European, American, and Asian populations. In order to establish genome-wide significance, future studies must analyze a greater sample size. To the best of our knowledge, the present pilot study is the first to investigate the association between these 32 SNPs and psoriasis in a Mexican Mestizo population.

\section{Introduction}

Psoriasis is a multisystem chronic inflammatory disease, which affects $\sim 2 \%$ of the worldwide population (1). It is a multifactorial disease that is characterized by genetic heterogeneity, high heritability, varying age of onset and immunological risk factors (2). In addition, its prevalence has been shown to vary among different populations (2), and numerous clinical variants have previously been identified (3).

Due to the relatively high heritability of psoriasis, genetic analyses, including linkage and/or association studies, have been conducted worldwide in order to identify genes that may affect the risk of developing psoriasis (2). Genome-wide association studies have implicated 36 susceptibility loci in the pathogenesis of psoriasis (4), of which the most relevant is located within the major histocompatibility complex (MHC) on chromosome $6 \mathrm{p} 21.3$, adjacent to the MHC class I-C (HLA-C) gene, which is known as psoriasis susceptibility gene 1 (PSORS1) (5).

Various single nucleotide polymorphisms (SNPs) have previously been associated with an increased risk of developing psoriasis. These SNPs are involved in various processes, including: Skin barrier functions [late cornified envelope $(L C E) 3 E$ and $3 C$ ], interleukin $(I L)-23$ signaling $(I L-23 A, I L-23 R$, and $I L-12 B)$, nuclear factor- $\kappa \mathrm{B}$ and inter- 
feron signaling [nuclear factor of kappa light polypeptide gene enhancer in B-cells inhibitor-alpha (NFKBIA), LINC01185, tyrosine kinase 2 ( $T Y K 2)$, potassium voltage-gated channel subfamily $\mathrm{H}$ member 7 (KCNH7), IL-28RA, tumor necrosis factor (TNF)- $\alpha$-induced protein 3 (TNFAIP3), annexin A6 (ANXA6), and the IL-17 cell response [REV3L, TYK2, and $I L-23 R]$ (2). In contrast to their risk association, a number of these SNPs have also been shown to protect against psoriasis (6), whereas other studies have not detected an association between these SNPs and psoriasis $(7,8)$. These discrepancies may be due to genetic variations in the populations studied.

Previous studies investigating the association between SNPs and psoriasis have predominantly analyzed European, American, and Asian populations $(2,4,6,7)$; however, it is currently unclear whether these SNPs may also be associated with psoriasis in the Mexican population. Therefore, the present study aimed to investigate the genotypic and allelic frequencies of 32 SNPs at 24 loci, and their association with psoriasis, in a Mestizo population from northeast Mexico.

\section{Materials and methods}

Ethics. The present study (register no. DE11-004) was conducted at the Department of Genetics, University Hospital 'Dr. José Eleuterio González’ (Monterrey, México), with approval from the Committee for Ethics, Research and Biosecurity of the School of Medicine, University Hospital 'Dr. José Eleuterio González', Autonomous University of Nuevo León.

Subjects. Written informed consent was obtained from all the patients enrolled, following an explanation of the nature of the study. A total of 46 patients ( 32 males and 14 females; age, 26-72 years), who had been diagnosed with chronic plaque psoriasis, were recruited from the Dermatology Outpatient Clinic at the University Hospital 'Dr. José Eleuterio González' between November 2011 and May 2012. Patients diagnosed with other clinical subtypes of psoriasis or other genetic diseases, as well as affected relatives of the patients in the study, were excluded.

Controls. A total of 103 peripheral blood samples (from 56 males and 47 females; age, 26-72 years) from control subjects without psoriasis (age, 26-72 years) were obtained from the DNA Bank of the Department of Genetics at the University Hospital 'Dr. José Eleuterio González'.

SNP selection. A total of 32 SNPs from 24 genes and 2 intergenic regions, which were previously associated with psoriasis in various populations, were selected. The SNPs included in the study were associated with the following genes: $H L A-C, I L-12 B, I L-23 R, I L-23 A, I L-28 R A, T N F-\alpha$, ring finger protein-114 ( $R N F 114)$, cyclin-dependent kinase 5 regulatory subunit-associated protein 1-like 1 (CDKAL1), $L C E 3 D$, signal transducer and activator of transcription 4 (STAT4), LINC01185, KCNH7, IL-13, ANXA6, endoplasmic reticulum aminopeptidase 1 (ERAP1), TNFAIP3, REV3L, Leptin, NFKBIA, F-box and leucine-rich repeat protein 19 (FBXL19), nitric oxide synthase 2 (NOS2), cluster of differ- entiation $40(C D 40)$, nuclear receptor coactivator 5 (NCOA5), and $A D A M$ metallopeptidase domain 33 (ADAM33). These genes are primarily associated with immune and inflammatory responses. The included genes were selected on the basis of previously reported odds ratios (OR), which suggested that they were closely associated with psoriasis (2).

Genotyping. Molecular analyses were conducted using the TaqMan ${ }^{\circledR}$ assay (Applied Biosystems; Thermo Fisher Scientific, Inc., Waltham, MA, USA), and were analyzed using the OpenArray ${ }^{\circledR}$ NT Genotyping system (Applied Biosystems; Thermo Fisher Scientific, Inc.). DNA was extracted from $200 \mu \mathrm{L}$ EDTA-treated whole blood samples, using the QIAamp Blood Mini kit on the automated QIAcube system (Qiagen, Hilden, Germany). Purified DNA was collected in a final volume of $150 \mu \mathrm{L}$ and stored at $-20^{\circ} \mathrm{C}$ until use. DNA for OpenArray (OA) analysis was diluted at a concentration of $50 \mathrm{ng} / \mu \mathrm{l}$ and a ratio of A260/280 and A260/230 of 1.6-1.9. A non-template control, which consisted of DNase-free double-distilled water, was used in each plate assay. The DNA sample (50 ng/ $\mu \mathrm{l})$ and TaqMan OpenArray Master Mix (Applied Biosystems; Thermo Fisher Scientific, Inc.) were mixed in a 384-well plate, and transferred to the OA plate using an autoloader, after which the OA plate was filled with immersion fluid and sealed with glue. Multiplex TaqMan ${ }^{\circledR}$ assay reactions were carried out in a Dual Flat Block GeneAmp PCR system 9700 (Applied Biosystems; Thermo Fisher Scientific, Inc.), and the PCR cycling conditions were as follows: An initial step at $93^{\circ} \mathrm{C}$ for $10 \mathrm{~min}$; followed by 50 cycles at $95^{\circ} \mathrm{C}$ for $45 \mathrm{sec}, 94^{\circ} \mathrm{C}$ for $13 \mathrm{sec}$ and $53^{\circ} \mathrm{C}$ for $2 \mathrm{~min}, 14 \mathrm{sec}$; followed by a final step at $25^{\circ} \mathrm{C}$ for $2 \mathrm{~min}$. The samples were maintained at $4^{\circ} \mathrm{C}$ until further use. The plate was designed to analyze 32 TaqMan ${ }^{\circledR}$ assays for each sample. The allele analysis was conducted using the TaqMan ${ }^{\circledR}$ Genotyper Software 1.0, with the default parameters, according to the manufacturer's protocol (Applied Biosystems; Thermo Fisher Scientific, Inc.). The accuracy of the genotyping was assessed by comparisons with 15 samples, which had been genotyped three times, resulting in 45 comparison per SNP.

Statistical analysis. Genetic analyses were conducted using the Golden Helix SNP \& Variation Suite 7.6 program (Golden Helix, Inc., Bozeman, MT, USA). The 32 SNPs were analyzed for deviation from the Hardy-Weinberg equilibrium using the Fisher's exact test $(\mathrm{P}<0.01$ was considered to indicate a statistically significant difference). An association study was performed using the Basic Allelic test and Fisher's exact test in order to assess ORs, 95\% confidence intervals (CIs) and P-values. In addition, Bonferroni P-values and false discovery rates (FDR) were calculated in order to exclude spurious associations. $\mathrm{P} \leq 0.05 / 32$ SNPs $\left(1.56 \times 10^{-3}\right)$ was considered to indicate a statistically significant difference.

\section{Results}

Clinical characteristics of the study population. The genetic analysis included samples from 46 patients and 103 controls (age range, 26-72 years). Of the patients, 32 were male $(69.56 \%)$ and 14 were female $(30.43 \%)$, of which 6 patients 
Table I. SNPs analyzed in patients with psoriasis and controls.

\begin{tabular}{|c|c|c|c|c|c|c|c|c|c|c|}
\hline \multirow[b]{2}{*}{ Gene/SNP } & \multirow[b]{2}{*}{ SNP } & \multirow[b]{2}{*}{$\mathrm{Chr}$} & \multicolumn{3}{|c|}{ Fisher's Exact } & \multirow[b]{2}{*}{ OR $(95 \% \mathrm{CI})$} & \multicolumn{2}{|c|}{ Allele Freq. } & \multicolumn{2}{|c|}{ Fisher's HWE P } \\
\hline & & & $\mathrm{P}$ & Bonf. P & FDR & & Cases & Controls & Cases & Controls \\
\hline$H L A-C$ & rs10484554 & 6 & 0.003 & 0.100 & 0.100 & $\begin{array}{l}\text { Т } 3.51(1.54-7.99) \\
\text { С } 0.28(0.13-0.65)\end{array}$ & $\begin{array}{l}0.167 \\
0.833\end{array}$ & $\begin{array}{l}0.054 \\
0.946\end{array}$ & 0.582 & 1.000 \\
\hline$H C G 27$ & rs1265181 & 6 & 0.010 & 0.326 & 0.163 & $\begin{array}{l}\text { C } 2.83(1.29-6.23) \\
\text { G } 0.35(0.16-0.78)\end{array}$ & $\begin{array}{l}0.163 \\
0.837\end{array}$ & $\begin{array}{l}0.064 \\
0.936\end{array}$ & 0.009 & 0.003 \\
\hline RNF114 & rs6125829 & 20 & 0.014 & 0.444 & 0.148 & $\begin{array}{l}\text { T } 0.51(0.30-0.86) \\
\text { G } 1.98(1.17-3.35)\end{array}$ & $\begin{array}{l}0.318 \\
0.682\end{array}$ & $\begin{array}{l}0.480 \\
0.520\end{array}$ & 0.489 & 0.070 \\
\hline \multirow[t]{3}{*}{$I L-12 B$} & rs3213094 & 5 & 0.018 & 0.569 & 0.142 & $\begin{array}{l}\text { Т } 0.51(0.30-0.89) \\
\text { С } 1.94(1.13-3.36)\end{array}$ & $\begin{array}{l}0.267 \\
0.733\end{array}$ & $\begin{array}{l}0.414 \\
0.586\end{array}$ & 0.701 & 0.100 \\
\hline & rs3212227 & 5 & 0.025 & 0.805 & 0.161 & $\begin{array}{l}\text { G } 0.53(0.31-0.92) \\
\text { T } 1.88(1.09-3.24)\end{array}$ & $\begin{array}{l}0.267 \\
0.733\end{array}$ & $\begin{array}{l}0.406 \\
0.594\end{array}$ & 0.701 & 0.408 \\
\hline & rs6887695 & 5 & 0.269 & 1.000 & 0.614 & $\begin{array}{l}\text { C } 0.72(0.41-1.27) \\
\text { G } 1.39(0.79-2.44)\end{array}$ & $\begin{array}{l}0.239 \\
0.761\end{array}$ & $\begin{array}{l}0.304 \\
0.696\end{array}$ & 0.698 & 0.484 \\
\hline$A N X A 6$ & rs17728338 & 5 & 0.055 & 1.000 & 0.293 & $\begin{array}{l}\text { A } 2.41(1.00-5.77) \\
\text { G } 0.42(0.17-0.99)\end{array}$ & $\begin{array}{l}0.120 \\
0.880\end{array}$ & $\begin{array}{l}0.053 \\
0.947\end{array}$ & 0.103 & 0.245 \\
\hline \multirow[t]{3}{*}{$A D A M 33$} & rs512625 & 20 & 0.078 & 1.000 & 0.356 & $\begin{array}{l}\text { A } 1.75(0.96-3.19) \\
\text { G } 0.57(0.31-1.04)\end{array}$ & $\begin{array}{l}0.250 \\
0.750\end{array}$ & $\begin{array}{l}0.160 \\
0.840\end{array}$ & 1.000 & 0.284 \\
\hline & rs597980 & 20 & 0.609 & 1.000 & 0.974 & $\begin{array}{l}\text { G } 1.18(0.71-1.94) \\
\text { A } 0.85(0.52-1.40)\end{array}$ & $\begin{array}{l}0.489 \\
0.511\end{array}$ & $\begin{array}{l}0.448 \\
0.552\end{array}$ & 1.000 & 0.067 \\
\hline & rs677044 & 20 & 0.524 & 1.000 & 0.931 & $\begin{array}{l}\text { G } 1.27(0.69-2.33) \\
\text { A } 0.79(0.43-1.45)\end{array}$ & $\begin{array}{l}0.217 \\
0.783\end{array}$ & $\begin{array}{l}0.180 \\
0.820\end{array}$ & 0.661 & 0.736 \\
\hline \multirow[t]{3}{*}{$L T A ; T N F ; L T B$} & rs361525 & 6 & 0.084 & 1.000 & 0.337 & $\begin{array}{l}\text { A } 2.08(0.95-4.58) \\
\text { G } 0.48(0.22-1.06)\end{array}$ & $\begin{array}{l}0.144 \\
0.856\end{array}$ & $\begin{array}{l}0.075 \\
0.925\end{array}$ & 0.206 & 0.433 \\
\hline & rs1800629 & 6 & 0.097 & 1.000 & 0.346 & $\begin{array}{l}\text { A } 2.20(0.93-5.18) \\
\text { G } 0.46(0.19-1.07)\end{array}$ & $\begin{array}{l}0.120 \\
0.880\end{array}$ & $\begin{array}{l}0.058 \\
0.942\end{array}$ & 0.103 & 1.000 \\
\hline & rs1799964 & 6 & 0.642 & 1.000 & 0.978 & $\begin{array}{l}\text { C } 0.84(0.45-1.57) \\
\text { Т } 1.19(0.64-2.23)\end{array}$ & $\begin{array}{l}0.185 \\
0.815\end{array}$ & $\begin{array}{l}0.213 \\
0.787\end{array}$ & 1.000 & 0.039 \\
\hline$I L-13$ & rs20541 & 5 & 0.103 & 1.000 & 0.329 & $\begin{array}{l}\text { G } 1.55(0.94-2.54) \\
\text { A } 0.65(0.39-1.06)\end{array}$ & $\begin{array}{l}0.565 \\
0.435\end{array}$ & $\begin{array}{l}0.456 \\
0.544\end{array}$ & 0.227 & 0.003 \\
\hline NFKBIA & rs8016947 & 14 & 0.155 & 1.000 & 0.451 & $\begin{array}{l}\text { T } 0.64(0.36-1.15) \\
\text { G } 1.56(0.87-2.82)\end{array}$ & $\begin{array}{l}0.207 \\
0.793\end{array}$ & $\begin{array}{l}0.289 \\
0.711\end{array}$ & 0.659 & 0.095 \\
\hline NCOA5 & rs2903908 & 20 & 0.222 & 1.000 & 0.592 & $\begin{array}{l}\text { C } 0.62(0.29-1.31) \\
\text { Т } 1.62(0.76-3.44)\end{array}$ & $\begin{array}{l}0.109 \\
0.891\end{array}$ & $\begin{array}{l}0.165 \\
0.835\end{array}$ & 1.000 & 1.000 \\
\hline NOS2 & rs4795067 & 17 & 0.267 & 1.000 & 0.657 & $\begin{array}{l}\text { G } 1.39(0.82-2.37) \\
\text { A } 0.72(0.42-1.22)\end{array}$ & $\begin{array}{l}0.337 \\
0.663\end{array}$ & $\begin{array}{l}0.267 \\
0.733\end{array}$ & 1.000 & 0.799 \\
\hline$C D K A L 1$ & rs6908425 & 6 & 0.286 & 1.000 & 0.610 & $\begin{array}{l}\text { Т } 0.68(0.36-1.28) \\
\text { С } 1.46(0.78-2.74)\end{array}$ & $\begin{array}{l}0.174 \\
0.826\end{array}$ & $\begin{array}{l}0.235 \\
0.765\end{array}$ & 0.601 & 0.788 \\
\hline$I L-28 R A$ & rs4649203 & 1 & 0.287 & 1.000 & 0.574 & $\begin{array}{l}\text { G } 0.56(0.22-1.44) \\
\text { A } 1.77(0.69-4.53)\end{array}$ & $\begin{array}{l}0.065 \\
0.935\end{array}$ & $\begin{array}{l}0.110 \\
0.890\end{array}$ & 1.000 & 1.000 \\
\hline$L C E 3 D$ & rs4112788 & 1 & 0.523 & 1.000 & 0.984 & $\begin{array}{l}\text { A } 1.21(0.74-1.99) \\
\text { G } 0.83(0.50-1.36)\end{array}$ & $\begin{array}{l}0.435 \\
0.565\end{array}$ & $\begin{array}{l}0.388 \\
0.612\end{array}$ & 0.382 & 0.305 \\
\hline KCNH7 & rs17716942 & 2 & 0.597 & 1.000 & 1.000 & $\begin{array}{l}\mathrm{C} 0.67(0.21-2.11) \\
\mathrm{T} 1.50(0.47-4.72)\end{array}$ & $\begin{array}{l}0.043 \\
0.957\end{array}$ & $\begin{array}{l}0.064 \\
0.936\end{array}$ & 1.000 & 1.000 \\
\hline IL-23A;STAT2 & rs2066808 & 12 & 0.651 & 1.000 & 0.948 & $\begin{array}{l}\text { G } 1.29(0.55-3.03) \\
\text { A } 0.78(0.33-1.83)\end{array}$ & $\begin{array}{l}0.098 \\
0.902\end{array}$ & $\begin{array}{l}0.078 \\
0.922\end{array}$ & 0.351 & 1.000 \\
\hline$L E P$ & rs7799039 & 7 & 0.702 & 1.000 & 0.977 & $\begin{array}{l}\text { A } 1.11(0.67-1.83) \\
\text { G } 0.90(0.55-1.49)\end{array}$ & $\begin{array}{l}0.413 \\
0.587\end{array}$ & $\begin{array}{l}0.388 \\
0.612\end{array}$ & 0.225 & 0.678 \\
\hline TNFAIP3 & rs610604 & 6 & 0.705 & 1.000 & 0.940 & $\begin{array}{l}\text { G } 0.89(0.54-1.46) \\
\text { T } 1.12(0.68-1.85)\end{array}$ & $\begin{array}{l}0.413 \\
0.587\end{array}$ & $\begin{array}{l}0.442 \\
0.558\end{array}$ & 0.225 & 1.000 \\
\hline $\begin{array}{l}\text { LOC } 101927805 \\
-L O C 10537697\end{array}$ & rs6809854 & 3 & 0.779 & 1.000 & 0.997 & $\begin{array}{l}\text { G } 0.91(0.52-1.60) \\
\text { A } 1.10(0.63-1.92)\end{array}$ & $\begin{array}{l}0.267 \\
0.733\end{array}$ & $\begin{array}{l}0.285 \\
0.715\end{array}$ & 0.245 & 0.806 \\
\hline STAT4 & rs7574865 & 2 & 0.800 & 1.000 & 0.984 & $\begin{array}{l}\text { T } 1.10(0.67-1.80) \\
\text { G } 0.91(0.56-1.50)\end{array}$ & $\begin{array}{l}0.435 \\
0.565\end{array}$ & $\begin{array}{l}0.413 \\
0.587\end{array}$ & 0.227 & 0.546 \\
\hline
\end{tabular}


Table I. Continued.

\begin{tabular}{|c|c|c|c|c|c|c|c|c|c|c|}
\hline \multirow[b]{2}{*}{ Gene/SNP } & \multirow[b]{2}{*}{ SNP } & \multirow[b]{2}{*}{ Chr } & \multicolumn{3}{|c|}{ Fisher's Exact } & \multirow[b]{2}{*}{ OR $(95 \% \mathrm{CI})$} & \multicolumn{2}{|c|}{ Allele Freq. } & \multicolumn{2}{|c|}{ Fisher's HWE P } \\
\hline & & & $\mathrm{P}$ & Bonf. P & FDR & & Cases & Controls & Cases & Controls \\
\hline$R E V 3 L$ & rs240993 & 6 & 0.800 & 1.000 & 0.948 & $\begin{array}{l}\text { C } 0.91(0.55-1.49) \\
\text { T } 1.10(0.67-1.81)\end{array}$ & $\begin{array}{l}0.413 \\
0.587\end{array}$ & $\begin{array}{l}0.437 \\
0.563\end{array}$ & 0.545 & 0.228 \\
\hline$I L-23 R$ & rs7530511 & 1 & 0.858 & 1.000 & 0.980 & $\begin{array}{l}\text { Т } 0.92(0.44-1.89) \\
\text { С } 1.09(0.53-2.25)\end{array}$ & $\begin{array}{l}0.130 \\
0.870\end{array}$ & $\begin{array}{l}0.141 \\
0.859\end{array}$ & 0.561 & 0.414 \\
\hline LINC01185 & rs702873 & 2 & 0.887 & 1.000 & 0.978 & $\begin{array}{l}\text { Т } 0.92(0.52-1.61) \\
\text { С } 1.09(0.62-1.92)\end{array}$ & $\begin{array}{l}0.250 \\
0.750\end{array}$ & $\begin{array}{l}0.267 \\
0.733\end{array}$ & 0.242 & 0.449 \\
\hline$E R A P 1 ; C A S T$ & rs27524 & 5 & 0.887 & 1.000 & 0.946 & $\begin{array}{l}\text { A } 0.94(0.53-1.65) \\
\text { G } 1.07(0.61-1.88)\end{array}$ & $\begin{array}{l}0.250 \\
0.750\end{array}$ & $\begin{array}{l}0.262 \\
0.738\end{array}$ & 0.430 & 0.071 \\
\hline FBXL19 & rs12924903 & 16 & 1.000 & 1.000 & 1.000 & $\begin{array}{l}\text { A } 0.98(0.59-1.63) \\
\text { G } 1.02(0.61-1.69)\end{array}$ & $\begin{array}{l}0.380 \\
0.620\end{array}$ & $\begin{array}{l}0.385 \\
0.615\end{array}$ & 0.032 & 0.529 \\
\hline$C D 40$ & rs4810485 & 20 & 1.000 & 1.000 & 1.000 & $\begin{array}{l}\text { T } 1.03(0.56-1.90) \\
\text { G } 0.97(0.53-1.78)\end{array}$ & $\begin{array}{l}0.207 \\
0.793\end{array}$ & $\begin{array}{l}0.201 \\
0.799\end{array}$ & 1.000 & 1.000 \\
\hline
\end{tabular}

$\mathrm{P}<0.05$ indicates a statistically significant difference. $\mathrm{CI}$, confidence interval; OR, odds ratio; $\mathrm{SNP}$, single nucleotide polymorphism; $\mathrm{P}, \mathrm{P}-\mathrm{value}$; Bonf. Bonferroni correction; FDR, false discovery rate; HWE, Hardy-Weinberg Equilibrium; Chr, chromosome; HLA-C, major histocompatibility complex class I-C; HCG27, HLA complex group 27; RNF114, ring finger protein-114; IL, interleukin; ANXA6, annexin A6; ADAM33, ADAM metallopeptidase domain 33; LTA, lymphotoxin alpha; TNF, tumor necrosis factor; LTB, lymphotoxin beta; NFKBIA, nuclear factor of kappa light polypeptide gene enhancer in B-cells inhibitor-alpha; NCOA5, nuclear receptor coactivator 5; NOS2, nitric oxide synthase 2; CDKAL1, cyclin-dependent kinase 5 regulatory subunit-associated protein 1-like $1 ; L C E$, late cornified envelope; $K C N H 7$, potassium voltage-gated channel subfamily $\mathrm{H}$ member 7; STAT, signal transducer and activator of transcription; LEP, leptin; TNFAIP3, TNF- $\alpha$-induced protein 3; REV3L, REV3-like polymerase (DNA directed) zeta catalytic subunit; LINC01185, long intergenic non-protein coding RNA 1185; ERAP1, endoplasmic reticulum aminopeptidase 1; CAST, calpastatin; FBXL19, F-box and leucine-rich repeat protein 19; CD40, cluster of differentiation 40.

$(13.04 \%)$ had a family history of psoriasis. A total of 17 patients $(36.95 \%)$ had mild, 25 patients $(54.34 \%)$ had moderate, and 2 patients (4.34\%) presented severe psoriasis. Articular and nail involvement were detected in 4 (8.69\%) and $18(39.13 \%)$ patients respectively.

Genotype frequencies and $O R$. Genotype frequencies of the 32 SNPs in both groups are presented in Table I. For the control group, two of the SNPs (the rs1265181 allele of the $H G C 27$ gene and the rs20541 allele of the $I L-13$ gene) were not in Hardy-Weinberg equilibrium $(\mathrm{P}<0.01)$.

Of the 32 SNPs, six were shown to confer risk for psoriasis, including: $H L A-C$ rs10484554 (T allele; OR 3.51; 95\% CI 1.54-7.99), HCG27 rs1265181 (C allele; OR 2.83; 95\% CI 1.29-6.23), ANXA6 rs17728338 (A allele; OR 2.41; 95\% CI 1.00-5.77), RNF114 rs6125829 (G allele; OR 1.98; $95 \%$ CI 1.17-3.35), $I L-12 B$ rs3213094 (C allele; OR 1.94; 95\% CI 1.13-3.36) and $I L-12 B$ rs3212227 (T allele; OR 1.88; 95\% CI 1.09-3.24) (Table I) (Fisher's exact test $\mathrm{P}<0.05$ ). However, following FDR and Bonferroni correction (threshold for genome-wide significance, $\mathrm{P}<1.56 \times 10^{-3}$ ), statistical significance was no longer detected.

\section{Discussion}

In the present study, six SNPs corresponding to different genes were associated with an increased risk of developing psoriasis, of which the HLA-C rs10484554 SNP exhibited the highest (T allele; OR 3.51) and the $I L-12 B$ rs3213094 SNP exhibited the lowest OR (C allele; OR 1.94).
The HLA-C gene has most frequently been associated with psoriasis in previous studies investigating other populations (9-11). This locus is known as PSORS1 and is located in the 6p21.3 genomic region. The SNP rs10484554 (12) is located $34.7 \mathrm{~kb}$ upstream of the $H L A-C$ start site, and has previously been associated with immune responses, including antigen presentation and natural killer cell regulation (13).

The rs1265181 SNP of the HCG27 gene has previously been shown to have a markedly positive correlation with psoriasis in the Chinese population $(2,13,14)$.

The rs6125829 SNP of the RNF114 gene was previously associated with psoriasis in British patients of north European descent (13), and in the present study. The RNF114 gene localizes to the $20 \mathrm{q} 13$ locus and encodes a cytosolic protein that has an important role in the ubiquitin pathway. A previous study has detected abundant RNF114 expression in disease-associated tissues, including $\mathrm{CD}^{+}{ }^{+} \mathrm{T}$-lymphocytes, dendritic cells and the skin (15).

The rs3212227 and rs3213094 SNPs of the $I L-12 B$ gene have previously been associated with psoriasis in European, North American, and Japanese populations (14-16). These SNPs are located in the 5q31.1-q33.1 chromosomal region, which is known as PSORS11. In addition, the rs3212227 SNP has previously been associated with various other autoimmune diseases, including type 1 diabetes mellitus, due to its effects on T-helper $\left(\mathrm{T}_{\mathrm{h}}\right) 1$ cells (16). The $I L-12 B$ gene encodes the p40 subunit of IL-12, which is also found in IL-23. This is consistent with previous studies that have associated IL-12 and IL-23 with psoriasis (16-18). IL-12 induces T-helper cells, whereas IL-23 expands and maintains $\mathrm{T}_{\mathrm{h}} 17$ cells. In 
previous studies, biological therapies against the p40 subunit were effective in patients with psoriasis (18-21). The results of the present study suggested that the $I L-12 B$ rs $3212227 \mathrm{~T}$ and rs3213094 C SNPs confer an increased risk for psoriasis; however, the two $I L-23$ SNPs that were analyzed, including $I L-23 R$ rs7530511 and $I L-23 A$ rs2066808, did not. It would be interesting to determine whether the $I L-12 B$ polymorphisms are associated with the response to drugs targeting the p40 subunit in the Mexican population.

The ANXA6 gene belongs to the conserved annexin protein family, which is a group of $\mathrm{Ca}^{2+}$-dependent membrane binding proteins. It is an important candidate gene for developing psoriasis, since it is involved in plasma membrane repair. ANXA6 may have a role in receptor signaling at the cell surface, growth factor and lipoprotein receptor trafficking, $\mathrm{Ca}^{2+}$-channel activity and $\mathrm{T}$ cell activation (22). In the present study, ANXA6 was associated with psoriasis in the Mexican Mestizo population, and has also previously been associated with psoriasis in the Han Chinese population (23).

The present study demonstrated that the allele frequencies of $r s 20541$ and $r s 1265181$ were similar to reported frequencies for Mexican Ancestry in Los Angeles (CA, USA); therefore, the Hardy-Weinberg disequilibrium detected here may be due to a missense mutation in rs20541 (445 Gln>Arg). For rs1265181, the disequilibrium may be due to population substructure in this intergenic region between loci associated to multiple inmunes diseases and the HLA complex group 27, which is non-protein coding; however, further studies are necessary to fully elucidate this. The other SNPs analyzed in the present study did not exhibit an association with psoriasis in the Mexican Mestizo population. It is important to mention that the alternative non-risk associated alleles from the various genes may confer protection against psoriasis (protection indicated by $\mathrm{OR}<1$ ).

To the best of our knowledge, the present study is the first to investigate the association between genetic regions that have previously been associated with psoriasis in other populations, including Asian and European populations, and psoriasis in the Mexican Mestizo population . The results of the present study suggested that SNPs in the $H L A-C, I L-12 B$, $H C G 27, A N X A 6$ and $R N F 114$ genes were associated with psoriasis in a Mestizo population from northeastern Mexico. Following FDR and Bonferroni correction (threshold for genome-wide significance $\mathrm{P}<1.56 \times 10^{-3}$ ), a statistically significant difference between the patient and control groups was no longer evident; however, as the case control relationship was $1: 2.3$, it is necessary to assess a larger group of patients in the future in order to increase the statistical power and validate these preliminary results. Furthermore, future studies should include subjects from diverse Mexican populations, since there is significant genetic heterogeneity among the Mexican population. The Mexican population is a good model for genetic studies, due to the vast ethnic diversity among native and Mestizo populations. The results of the present study may be considered a reference in genetic studies of characterized populations investigating gene frequencies and associations.

In conclusion, the present study observed that in Mexican patients with plaque psoriasis, SNPs from different genes associated with immune response or membrane cell repair confer an increased risk for disease development.

\section{References}

1. Menter A, Gottlieb A, Feldman SR, Van Voorhees AS, Leonardi CL, Gordon KB, Lebwohl M, Koo JY, Elmets CA, et al: Guidelines of care for the management of psoriasis and psoriatic arthritis: Section 1. Overview of psoriasis and guidelines of care for the treatment of psoriasis with biologics. J Am Acad Dermatol 58: 826-850, 2008.

2. Oka A, Mabuchi T, Ozawa A and Inoko H: Current understanding of human genetics and genetic analysis of psoriasis. J Dermatol 39: 231-241, 2012.

3. Griffiths CE, Christophers E, Barker JN, Chalmers RJ, Chimenti S, Krueger GG, Leonardi C, Menter A, Ortonne JP and Fry L: A classification of psoriasis vulgaris according to phenotype. Br J Dermatol 156: 258-262, 2007.

4. Tsoi LC, Spain SL, Knight J, Ellinghaus E, Stuart PE, Capon F, Ding J, Li Y, Tejasvi T, Gudjonsson JE, et al: Identification of 15 new psoriasis susceptibility loci highlights the role of innate immunity. Nat Genet 44: 1341-1348, 2012.

5. Nestle FO, Kaplan DH and Barker J: Psoriasis. N Engl J Med 361: 496-509, 2009.

6. Capon F, Di Meglio P, Szaub J, Prescott NJ, Dunster C, Baumber L, Timms K, Gutin A, Abkevic V, Burden AD, et al: Sequence variants in the genes for the interleukin-23 receptor (IL23R) and its ligand (IL12B) confer protection against psoriasis. Human Genetics 122: 201-206, 2007.

7. Chang YT, Chou CT, Yu CW, Lin MW, Shiao YM, Chen CC, Huang $\mathrm{CH}$, Lee DD, Liu HN, Wang WJ and Tsai SF: Cytokine gene polymorphisms in Chinese patients with psoriasis. Br J Dermatol 156: 899-905, 2007.

8. Magalhães RF, Biral AC, Pancoto JA, Donadi EA, Mendes CT Jr, Magna LA and Kraemer MH: Human leukocyte antigen (HLA) and single nucleotide polymorphisms (SNPs) tumor necrosis factor (TNF)-alpha -238 and -308 as genetic markers of susceptibility to psoriasis and severity of the disease in a long-term follow-up Brazilian study. Int J Dermatol 49: 1133-1140, 2010.

9. Nair RP, Henseler T, Jenisch S, Stuart P, Bichakjian CK, Lenk W, Westphal E, Guo SW, Christophers E, Voorhees JJ and Elder JT: Evidence for two psoriasis susceptibility loci (HLA and 17q) and two novel candidate regions (16q and $20 \mathrm{p}$ ) by genome-wide scan. Hum Mol Genet 6: 1349-1356, 1997.

10. Enlund F, Samuelsson L, Enerbäck C, Inerot A, Wahlström J, Yhr M, Torinsson A, Martinsson T and Swanbeck G: Analysis of three suggested psoriasis susceptibility loci in a large Swedish set of families: Confirmation of linkage to chromosome 6p (HLA region) and to 17q, but not to 4q. Hum Hered 49: 2-8, 1999.

11. Zhang XJ, He PP, Wang ZX, Zhang J, Li YB, Wang HY, Wei SC, Chen SY, Xu SJ, Jin L, et al: Evidence for a major psoriasis susceptibility locus at 6p21 (PSORS1) and a novel candidate region at $4 \mathrm{q} 31$ by genome-wide scan in Chinese hans. J Invest Dermatol 119: 1361-1366, 2002.

12. Genetic Analysis of Psoriasis Consortium \& the Wellcome Trust Case Control Consortium 2, Strange A, Capon F, Spencer CC, Knight J, Weale ME, Allen MH, Barton A, Band G, Bellenguez C, et al: A genome-wide association study identifies new psoriasis susceptibility loci and an interaction between HLA-C and ERAP1. Nat Genet 42: 985-990, 2010.

13. Zhang XJ, Huang W, Yang S, Sun LD, Zhang FY, Zhu QX, Zhang FR, Zhang C, Du WH, Pu XM, et al: Psoriasis genome-wide association study identifies susceptibility variants within LCE gene cluster at 1q21. Nat Genet 41: 205-210, 2009.

14. Zhu KJ, Lv YM, Yin XY, Wang ZX, Sun LD, He SM, Cheng H, $\mathrm{Hu}$ DY, Zhang Z, Li Y, et al: Psoriasis regression analysis of MHC loci identifies shared genetic variants with vitiligo. PloS One 6: e23089, 2011.

15. Capon F, Bijlmakers MJ, Wolf N, Quaranta M, Huffmeier U, Allen M, Timms K, Abkevich V, Gutin A, Smith R, et al: Identification of ZNF313/RNF114 as a novel psoriasis susceptibility gene. Hum Mol Genet 17: 1938-1945, 2008.

16. Cargill M, Schrodi SJ, Chang M, Garcia VE, Brandon R, Callis KP, Matsunami N, Ardlie KG, Civello D, Catanese JJ, et al: A large-scale genetic association study confirms IL12B and leads to the identification of IL23R as psoriasis-risk genes. Am J Hum Genet 80: 273-290, 2007.

17. Nair RP, Ruether A, Stuart PE, Jenisch S, Tejasvi T, Hiremagalore R, Schreiber S, Kabelitz D, Lim HW, Voorhees JJ, et al: Polymorphisms of the IL12B and IL23R genes are associated with psoriasis. J Invest Dermatol 128: 1653-1661, 2008. 
18. Chien AL, Elder JT and Ellis CN: Ustekinumab: A new option in psoriasis therapy. Drugs 69: 1141-1152, 2009.

19. Gandhi M, Alwawi E and Gordon KB: Anti-p40 antibodies ustekinumab and briakinumab: blockade of interleukin-12 and interleukin-23 in the treatment of psoriasis. Seminars in cutaneous medicine and surgery 29: 48-52, 2010.

20. Griffiths CE, Strober BE, van de Kerkhof P, Ho V, Fidelus-Gort R, Yeilding N, Guzzo C, Xia Y, Zhou B, Li S, et al: Comparison of ustekinumab and etanercept for moderate-to-severe psoriasis. $\mathrm{N}$ Engl J Med 362: 118-128, 2010.
21. Kurzeja M, Rudnicka L and Olszewska M: New interleukin-23 pathway inhibitors in dermatology: Ustekinumab, briakinumab and secukinumab. Am J Clin Dermatol 12: 113-125, 2011.

22. Cornely R, Rentero C, Enrich C, Grewal T and Gaus K: Annexin A6 is an organizer of membrane microdomains to regulate receptor localization and signalling. IUBMB life 63: 1009-1017, 2011.

23. Sun LD, Cheng H, Wang ZX, Zhang AP, Wang PG, Xu JH, Zhu QX, Zhou HS, Ellinghaus E, Zhang FR, et al: Association analyses identify six new psoriasis susceptibility loci in the Chinese population. Nature Genet 42: 1005-1009, 2010. 